\title{
EVALUASI PARADE "OGOH-OGOH" SEBAGAI PENDUKUNG PENGEMBANGAN PARIWISATA BUDAYA DI KOTA DENPASAR
}

\author{
Ni Luh Putu Aristrawati \\ Email: putu.ristra@gmail.com
}

\begin{abstract}
This article discusses the evaluation of giant effigy ogoh-ogoh parade based on three aspects, such as the implementation of ogoh-ogoh parade, the contribution of ogoh-ogoh parade to the development of cultural tourism in Denpasar and to provide recommendations for strategy implementation of ogohogoh parade. This article was used culture tourism theory and evaluation theory. The data presented in this article was collected through observation and is complemented by interviews and other published sources with qualitative approach. The collected data analyzed by CIPP (Context, Input, Process and Product) evaluation model, expert judgment and qualitative descriptive. The result shows that parade ogoh-ogoh meet the criteria as an event that contributes in an effort to realize Denpasar as cultural city. Ogoh-ogoh parade also contributes as a supporting Denpasar in developing cultural tourism. The implementation strategy of ogoh-ogoh parade can be done through by the competition strategy and the increasing promotion strategy. From this article it can be concluded that as one of the cultural event in Denpasar city ogoh-ogoh parade can support the development of cultural tourism in the city of Denpasar, although in its implementation it requires sustain improvement.
\end{abstract}

Keywords: Evaluation, Ogoh-ogoh Parade, Cultural Tourism, Promotion Strategy

\section{Pendahuluan}

Sebagai upaya membangun Denpasar sebagai kota budaya sekaligus untuk menarik lebih banyak wisatawan, Pemerintah Kota Denpasar berupaya untuk mengembangkan berbagai event seni dan budaya dengan melibatkan peran serta masyarakat. Hal ini, misalnya dilakukan dengan menggelar Sanur Village Festival, Festival Pesona Pulau Serangan, Denpasar Festival, dan parade ogoh-ogoh (patung ukuran besar berbagai bentuk seperti raksasa dan figur-figur menyeramkan). Atraksi pawai ogoh-ogoh yang digelar setiap tahunnya sehari menjelang Hari Raya Nyepi merupakan salah satu jenis event madya yang diselenggarakan oleh Pemerintah Kota Denpasar melalui 
Dinas Kebudayaan Kota Denpasar (Bappeda Kota Denpasar, 2011:11).

Pawai ogoh-ogoh yang digelar di catus pata Catur Muka (perempatan Jalan Gajah Mada, Jl Veteran, Jln Udayana, Jln Surapati, dikenal sebagai titik nol Kota Denpasar) ternyata tidak hanya menarik masyarakat lokal namun juga wisatawan domestik dan mancanegara yang tengah berlibur di Kota Denpasar. Hanya saja promosi yang selama ini dilakukan oleh Pemerintah Kota Denpasar terkait parade ogoh-ogoh masih kurang, terutama infomasi ke pihak pelaku pariwisata khususnya travel agent. Hal ini tentunya harus mendapat perhatian yang serius dari Pemerintah Kota Denpasar, mengingat selain keterlibatan dari masyarakat tentunya keterlibatan komponen pariwisata juga diperlukan agar hasil kreativitas masyarakat ini mampu memberikan nilai tambah bagi perkembangan kepariwisataan budaya di Kota Denpasar.

Untuk menjaga kualitas dan entitas penyelenggaraan parade ogohogoh sebagai salah satu event di Kota Denpasar, tentunya perlu dilakukan evaluasi. Melalui evaluasi akan diperoleh informasi mengenai keberhasilan dan kegagalan pelaksanaan event sehingga dapat disusun rekomendasi terkait pelaksanaan event ke depannya. Hanya saja selama ini dalam penyelenggaraan event di Kota Denpasar belum ada indikator-indikator yang dijadikan dasar dalam melakukan evaluasi yang mampu memberikan gambaran dan ukuran tentang efektivitas sebuah event (Bappeda Kota Denpasar, 2011:25), termasuk parade ogoh-ogoh yang diselenggarakan oleh Dinas Kebudayaan Kota Denpasar.

Artikel ini membahas mengenai evaluasi parade ogoh-ogoh sebagai pendukung pengembangan pariwisata budaya di Kota Denpasar. Mengingat pada penyelenggaraan tahun 2014 muncul kembali protes dari sekaa teruna peserta seleksi dan juga terjadi penurunan jumlah peserta seleksi, serta terlebih lagi atraksi pawai ogoh-ogoh merupakan salah satu atraksi budaya di Kota Denpasar yang berbentuk hallmark event (Mahadewi, 2012:6) yang sudah dimasukkan dalam kalender event kepariwisataan Kota Denpasar, maka perlu dilakukan evaluasi terhadap parade ogoh-ogoh tahun 2014 secara menyeluruh.

Secara spesifik, artikel ini akan menelusuri tiga aspek yaitu implementasi parade ogoh-ogoh sebagai pendukung Denpasar sebagai kota budaya, analisis kontribusi parade ogoh-ogoh sebagai pendukung Denpasar dalam mengembangkan pariwisata budaya dan memberikan rekomendasi strategi pelaksanaan parade ogoh-ogoh. Artikel ini diharapkan dapat memberikan kontribusi bagi pemerintah Kota Denpasar dalam mengambil kebijakan terkait parade ogoh-ogoh, dapat meningkatkan kesadaran dan partisipasi masyarakat dalam pelestarian budaya dan tradisi lokal serta dapat membantu industri pariwisata dalam mendapatkan informasi tentang peluang pengemasan atraksi pawai ogoh-ogoh di Kota Denpasar menjadi paket wisata. 


\section{Teori dan Metode}

Kajian teori dimanfaatkan sebagai tuntunan dalam pemecahan masalah dan atau sebagai kerangka acuan yang mengarahkan penelitian. Ada dua teori yang dipakai untuk memecahkan permasalahan dalam artikel ini yaitu teori pariwisata budaya dan teori evaluasi. Teori pariwisata budaya digunakan untuk mengetahui implementasi parade ogoh-ogoh sebagai pendukung Denpasar sebagai Kota Budaya yang untuk selanjutnya dapat dirumuskan strategi pelaksanaan parade ogoh-ogoh bagi pengembangan pariwisata budaya di Kota Denpasar ke depannya. Sedangkan untuk mengetahui kontribusi parade ogoh-ogoh dipakai pendekatan teori evaluasi dengan menggunakan model evaluasi CIPP (Contexs, Input, Process, dan Product).

Untuk memperjelas apa yang akan dibahas dalam artikel ini, maka dipandang perlu untuk menguraikan beberapa konsep yang berkaitan. Adapun konsep-konsep yang digunakan antara lain: evaluasi kegiatan, parade ogoh-ogoh dan pengembangan pariwisata budaya. Artikel ini menggunakan pendekatan kualitatif karena peneliti hanya ingin memaparkan fenomena yang terjadi secara holistik dan dilakukan dengan memanfaatkan berbagai metode alamiah (Moleong, 2014:6). Pengumpulan data dilakukan melalui pengamatan di lapangan, wawancara serta data tambahan lainnya yang berasal dari sumber-sumber tertulis. Informan ditentukan secara purposive. Informan terdiri atas unsur Pemerintah Kota Denpasar, tim juri, sekaa teruna, seniman, budayawan serta pelaku pariwisata yaitu asosiasi pariwisata, hotel, dan travel agent.

Dalam artikel ini dianalisis menggunakan model evaluasi CIPP yang dikembangkan oleh Stufflebeam (Wirawan, 2012:57), yang dilakukan secara bertahap dengan berfokus pada empat aspek yang meliputi dimensi konteks, input, proses dan produk dari parade ogoh-ogoh tahun 2014. Sehubungan dengan parade ogoh-ogoh telah diselenggarakan sebelum penelitian ini dilaksanakan, maka untuk analisis data juga menggunakan metode dan teknik analisis expert judgement. Hasil analisis yang diperoleh dari model evaluasi CIPP kemudian divalidasi dengan meminta pendapat para ahli. Analisis data dalam penelitian ini dilakukan melalui analisis deskriptif kualitatif, yang bergerak diantara tiga komponen yaitu reduksi data, penyajian data dan penarikan kesimpulan (Miles dan Huberman, dalam Sugiyono, 2009:430).

\section{Ogoh-ogoh Unsur Budaya Unggulan Kota Denpasar}

Tradisi ogoh-ogoh merupakan salah satu unsur budaya unggulan Kota Denpasar. Berdasarkan hasil inventori Geriya, dkk (2010:14-19) spirit dan kreatif ogoh-ogoh termasuk ke dalam kategori unsur asli, khas, eklusif atau berdifusi dari Denpasar (pure local genious \& creativity) yang memiliki nilai tambah ganda budaya dan ekonomi. Menurut Geriya, dkk (2010:2) terdapat lima kriteria pokok budaya unggulan yang harus dipenuhi agar unsur-unsur budaya dapat dikategorikan sebagai budaya unggulan yaitu (1) memiliki sifat 
khas, beridentitas dan bermutu tinggi, (2) kokoh dalam basis sumber daya manusia, komunitas dan kelembagaan, (3) beretos kreatif dan mendifusikan kreativitas, (4) bernilai tambah secara ekonomi, teknologi, ekologi dan kultural; (5) terbuka dalam adaptasi lokal, nasional, internasional dan menjadi kebanggaan serta memperoleh apresiasi publik.

Jika dikaitkan dengan kriteria pokok budaya unggulan maka ogohogoh telah memenuhi kriteria pokok budaya unggulan di Kota Denpasar. Kriteria yang dimiliki oleh ogoh-ogoh sebagai salah satu budaya unggulan di Kota Denpasar meliputi: kekhasan dari tradisi ogoh-ogoh yang hanya ada di Bali sehingga ogoh-ogoh dapat dikategorikan sebagai hallmark event, keberadaan ogoh-ogoh sangat didukung oleh lembaga tradisional di Bali seperti desa pakraman, ${ }^{1}$ banjar ${ }^{2}$ dan sekaa teruna. ${ }^{3}$

Melalui penyelenggaraan parade ogoh-ogoh maka masyarakat khususnya generasi muda dapat menuangkan segala ide kreativitasnya mulai dari pembuatan hingga penyajian ogoh-ogoh. Dalam pembuatan ogoh-ogoh tidak hanya memberikan manfaat bagi pembuat ogoh-ogoh, namun juga memberikan nilai tambah baik secara ekonomi (memberikan peluang munculnya usaha kreatif, seperti penjualan bahan-bahan untuk membuat ogoh-ogoh), teknologi (pemanfaatan teknologi dalam pembuatan maupun penyajian ogoh-ogoh) maupun budaya (semakin bertahan dan lestarinya tradisi ogoh-ogoh).

Tradisi pawai ogoh-ogoh menjelang Hari Raya Nyepi yang dilaksanakan setiap tahun di Kota Denpasar tidak hanya menarik perhatian masyarakat lokal, tetapi juga wisatawan domestik maupun mancanegara. Pelaksanaan pawai ogoh-ogoh pada malam pangerupukan juga diliput oleh berbagai media baik media cetak maupun media elektronik, mulai dari media lokal, nasional hingga media internasional Ini menunjukkan bahwa tradisi ogohogoh dapat diterima oleh masyarakat mulai dari skala lokal, nasional hingga internasional.

Sejak ditetapkannya hari libur Nyepi (Tahun Baru Saka) bagi umat Hindu sebagai hari libur nasional (Keputusan Presiden Nomor 3 Tahun 1983 tentang Perubahan Atas Keputusan Presiden Nomor 251 Tahun 1967 tentang Hari-hari Libur (Indrayana, 2006:4-5) serta adanya himbauan dari Gubernur Bali, Prof. Dr. I.B. Mantra agar masyarakat membuat ogohogoh pada hari ngerupuk serangkaian dengan pelaksanaan Tawur Kesanga

1 Desa pakraman adalah kesatuan masyarakat hukum adat di Provinsi Bali yang mempunyai satu kesatuan tradisi dan tata krama pergaulan hidup masyarakat umat Hindu secara turun temurun dalam ikatan kahyangan tiga atau kahyangan desa yang mempunyai wilayah tertentu dan harta kekayaan sendiri serta berhak mengurus rumah tangganya sendiri (Peraturan Daerah Provinsi Bali Nomor 3 Tahun 2001 tentang Desa Pakraman).

2 Banjar pakraman adalah kelompok masyarakat yang merupakan bagian desa pakraman (Peraturan Daerah Provinsi Bali Nomor 3 Tahun 2001 tentang Desa Pakraman).

3 Sekaa Teruna adalah organisasi tradisional Bali di bidang kepemudaan yang ada di Bali. (Wayan P.Windia. 4 Januari 2004. "Membangun Sekaa Teruna" [Diunduh 30 Oktober 2014]. Sumber: URL: http://www. balipost.co.id/ balipostcetak/2004/1/4/k2.html). 
(Buku Panduan Ogoh-ogoh Pengerupukan, 2011:6), ogoh-ogoh seperti telah menjadi bagian dari rangkaian ritual Tawur Kesanga menjelang perayaan Hari Raya Nyepi di Bali dan terus berkembang hingga sekarang. Sebagai salah satu unsur budaya unggulan di Kota Denpasar, ogoh-ogoh dilestarikan dan dikembangkan secara berkelanjutan oleh Pemerintah Kota Denpasar bersama dengan seluruh komponen masyarakat.

\section{Parade Ogoh-Ogoh Pendukung Denpasar sebagai Kota Budaya}

Sejak pencanangan Denpasar sebagai kota berwawasan budaya, berbagai program di berbagai sektor kehidupan masyarakat dirancang dengan landasan kebudayaan Bali sebagai jati diri, salah satunya penyelenggaraan berbagai event dengan melibatkan peran serta masyarakat (Bappeda Kota Denpasar, 2010:18). Atraksi pawai ogoh-ogoh yang digelar setiap tahunnya sehari menjelang Hari Raya Nyepi di Kota Denpasar merupakan salah satu ajang kreativitas masyarakat yang berbasis budaya unggulan Kota Denpasar (Geriya, 2010:14-17).

Parade ogoh-ogoh di Kota Denpasar telah menjadi agenda rutin Pemerintah Kota Denpasar sejak tahun 2004 hingga sekarang. Pemerintah Kota Denpasar berinisiatif mengapresiasi karya ogoh-ogoh masyarakat ini dengan mengatur perhelatan ogoh-ogoh melalui lomba dan parade ogohogoh sejak tahun 2004 agar lebih tertib, aman, dan menarik. Inspirasi pelaksanaan parade ini sebagai langkah pencegahan terjadinya konflik akibat adanya gesekan atau benturan antarkelompok pengusung ogoh-ogoh.

Dalam buku Panduan Ogoh-ogoh Pengerupukan (2011:6) disebutkan bahwa tiga tahun pertama yaitu tahun 2004, 2005, dan 2006, lomba dan parade ogoh-ogoh dilaksanakan dalam rangka memeriahkan HUT Kota Denpasar yang jatuh setiap tanggal 27 Februari dengan mengambil lokasi dua kali di catus pata Catur Muka dan sekali dilaksanakan di wilayah Sanur. Walaupun pawai ogoh-ogoh dalam rangka HUT Kota Denpasar telah dilaksanakan pada bulan Februari, masyarakat Kota Denpasar masih tetap melaksanakan pawai ogoh-ogoh berkaitkan dengan perayaan Nyepi yang jatuh pada bulan Maret. Oleh karena itu, sejak tahun 2008 Pemerintah Kota Denpasar mulai memfasilitasi penyelenggaraan lomba dan parade ogoh-ogoh dalam rangka menyambut Hari Raya Nyepi yang dilaksanakan di kawasan Catur Muka Kota Denpasar dan daerah Sanur. 4

Setelah sempat vakum pada tahun 2009, Pemerintah Kota Denpasar melalui Dinas Kebudayaan Kota Denpasar kembali menggelar lomba dan parade ogoh-ogoh pada tahun 2010 yang dipusatkan di catus pata Catur Muka. Pada dasarnya mekanisme pelaksanaan parade ogoh-ogoh yang diselenggarakan oleh Dinas Kebudayaan Kota Denpasar dalam lima tahun terakhir (2010-2014) terdiri atas tiga tahapan yaitu sosialisasi, seleksi dan

4 Bali Post. 9 Maret 2008. "Pastika: Ogoh-ogoh Pantas Jadi Festival Internasional". [Diunduh 5 Oktober 2014]. Sumber: URL: http://www.balipost.co.id/balipostcetak/2008/3/9/b25.html 
pawai, hanya saja teknis pelaksanaannya berbeda-beda setiap tahunnya.

Penyelenggaraan parade ogoh-ogoh di Kota Denpasar memiliki keunggulan tersendiri karena ogoh-ogoh yang ditampilkan dalam parade merupakan ogoh-ogoh perwakilan dari masing-masing kecamatan yang telah lolos seleksi. Ogoh-ogoh yang ditampilkan setidaknya sudah memenuhi kriteria penilaian dari tim seleksi baik dari segi bentuk, tema, maupun penampilan ogoh-ogoh. Penampilan ogoh-ogoh peserta juga disertai dengan penataan gerak tari ogoh-ogoh yang diiringi dengan gamelan (alat musik tradisional) sehingga memiliki daya tarik bagi wisatawan maupun masyarakat yang menyaksikan.

Untuk menyelengggarakan sebuah event tentunya terdapat beberapa dimensi yang harus dipenuhi, di antaranya tujuan, tema, produk, lokasi, peserta, serta adanya pihak penyelenggara (Krosbacher, 2010:69). Jika dikaitkan dengan event parade ogoh-ogoh yang diselenggarakan oleh Pemerintah Kota Denpasar telah memenuhi unsur-unsur yang dimaksud. Adapun tinjauan dari masing-masing unsur dapat diuraikan sebagai berikut:

\subsection{Tujuan}

Tujuan dari diselenggarakannya parade ogoh-ogoh pada awalnya adalah untuk mengatur perhelatan ogoh-ogoh agar lebih tertib, aman, dan menarik. Selain itu pula, digelarnya parade ogoh-ogoh merupakan bentuk perhatian Pemerintah Kota Denpasar dalam menyikapi perkembangan kreativitas masyarakat Kota Denpasar, khususnya generasi muda yang terhimpun dalam wadah sekaa teruna sekaligus sebagai bentuk pelestarian tradisi ogoh-ogoh. Melalui pembuatan ogoh-ogoh maka sekaa teruna dapat menuangkan segala idenya dari awal pembuatan hingga ogoh-ogoh itu ditampilkan. Dengan dikembangkannya pariwisata budaya di Kota Denpasar diharapkan pelaksanaan parade ogoh-ogoh yang diselenggarakan sehari menjelang Hari Raya Nyepi dapat menjadi salah satu ikon budaya yang dapat menarik wisatawan sehingga secara tidak langsung nantinya akan dapat meningkatkan jumlah kunjungan wisatawan ke Kota Denpasar.

\subsection{Tema}

Pemilihan tema menjadi sangat penting di dalam proses pembuatan ogoh-ogoh, karena tema merupakan dasar atau inti di dalam menciptakan sebuah karya ogoh-ogoh. Jika pada awalnya bentuk ogoh-ogoh umumnya seram yang identik dengan bhuta kala sebagai tema ogoh-ogoh, telah berkembang ogoh-ogoh dengan tema yang bersifat kontemporer yang tidak mempunyai aturan atau pakem. Untuk meminimalisasi terjadinya kesalahan dalam pemaknaan pembuatan ogoh-ogoh, maka Pemerintah Kota Denpasar melalui Dinas Kebudayaan Kota Denpasar sesuai dengan hasil seminar yang digelar pada tahun 2011 telah menetapkan ketentuan bagi sekaa teruna 
untuk membuat ogoh-ogoh dengan tema bhuta kala yang mengacu pada sumber sastra Agama Hindu (Buku Panduan Ogoh-ogoh Pengerupukan, 2011:20).

\subsection{Produk}

Dengan diselenggarakannya parade ogoh-ogoh diharapkan masyarakat dapat memahami bentuk, fungsi, dan makna ogoh-ogoh ritual Nyepi. Nilainilai sastra yang dipakai sebagai acuan dalam pembuatan ogoh-ogoh secara tidak langsung dapat menambah pengetahuan tidak hanya bagi pembuat ogoh-ogoh namun juga bagi masyarakat maupun bagi wisatawan yang menikmati karya ogoh-ogoh itu sendiri. Ketika ogoh-ogoh divisualisasikan dengan karakter tokoh yang lengkap yaitu ada tokoh jahat dan tokoh baik yang dapat dilihat melalui ekspresi muka, gerak, warna-warna, simbolsimbol yang dibawa serta cerita yang ditampilkan, maka masyarakat dan wisatawan dapat memahami makna filosofis yang terdapat pada ogoh-ogoh. Hal ini tentunya juga akan memperkaya pengalaman budaya mereka.

\subsection{Lokasi}

Parade ogoh-ogoh yang diselenggarakan sehari menjelang Hari Raya Nyepi oleh Pemerintah Kota Denpasar melalui Dinas Kebudayaan Kota Denpasar yang dipusatkan di catus pata Catur Muka Denpasar. Di lokasi inilah para peserta yang telah lolos seleksi di masing-masing kecamatan menampilkan atraksi ogoh-ogoh disertai dengan penataan gerak tari ogohogoh yang diiringi gamelan. Lokasi diselenggarakannya sebuah event tentunya juga menjadi salah satu pertimbangan bagi wisatawan dalam menentukan pilihannya. Dipusatkannya pelaksanaan parade di catus pata Catur Muka menimbulkan permasalahan tersendiri, di antaranya di antaranya kemacetan yang tidak bisa dihindari di sejumlah jalan protokol Kota Denpasar khususnya di seputaran lapangan Puputan Badung akibat banyaknya ogoh-ogoh yang dipajang di pinggir jalan. Selain kemacetan menuju dan dari lokasi pelaksanaan parade, faktor lainnya adalah area bagi penonton sangat sempit serta kurang tertibnya para penonton yang berdesak-desakan dan saling dorong antara satu dengan lainnya sehingga menimbulkan ketidaknyamanan bagi wisatawan pada saat menikmati penampilan peserta parade ogoh-ogoh dan sering menjadi keluhan para wisatawan (lihat Foto 1).

\subsection{Peserta}

Dalam parade ogoh-ogoh di Kota Denpasar, dukungan atau partisipasi masyarakat lokal dapat dilihat dari dilibatkannya masyarakat, khususnya generasi muda yang terhimpun wadah sekaa teruna se-Kota Denpasar sebagai peserta. Dengan dilibatkannya sekaa teruna dalam kegiatan parade 


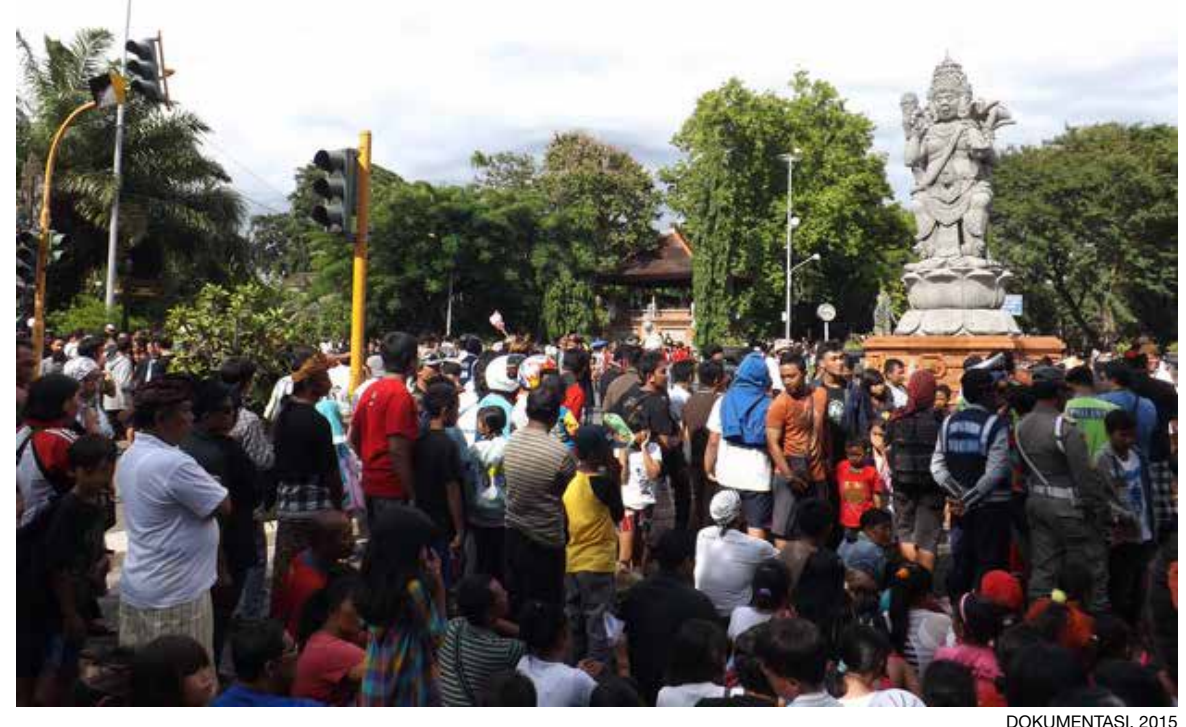

Foto 1. Masyarakat ramai menonton parade ogoh-ogoh di jantung Kota Denpasar.

ogoh-ogoh, maka mereka dapat berperan secara aktif dan secara tidak langsung ikut mempertahankan dan melestarikan tradisi pawai ogoh-ogoh. Untuk keterlibatan peserta seleksi, jika pada tahun 2010 melibatkan seluruh sekaa teruna se-Kota Denpasar baik yang berada di bawah banjar dinas maupun banjar adat, maka sejak tahun 2011 sekaa teruna yang dilibatkan sebagai peserta lebih difokuskan hanya yang berasal dari banjar adat saja.

Sebagai perwujudan komitmen Pemerintah Kota Denpasar guna mempertahankan tradisi dan memotivasi kreativitas sekaa teruna, seluruh sekaa teruna di Kota Denpasar mendapat dana pengembangan ekonomi kreatif. Dana tersebut dapat digunakan untuk kegiatan yang berbasis kreativitas, seperti bazzar dan termasuk pembuatan ogoh-ogoh. Selain mendapat dana pengembangan, bagi peserta yang lolos seleksi di masingmasing kecamatan juga mendapatkan dana pembinaan yang besarannya sama untuk masing-masing peserta dan terus meningkat setiap tahunnya.

\subsection{Pihak Penyelenggara}

Dalam pelaksanaan kegiatan, Dinas Kebudayaan bekerja sama dengan Majelis Madya Desa Pakraman (MMDP) Kota Denpasar, Sabha Upadesa Kota Denpasar, Parum Bendesa Desa Pakraman Kota Denpasar, Listibia Kota Denpasar dan SKPD Kecamatan se-Kota Denpasar. Untuk menjaga keamanan dan ketertiban selama penyelenggaraan parade ogoh-ogoh, Dinas Kebudayaan Kota Denpasar juga bekerja sama dengan pihak kepolisian dan pecalang se-Kota Denpasar.

Agar mendapat apresiasi yang tinggi dari wisatawan maupun pelaku 


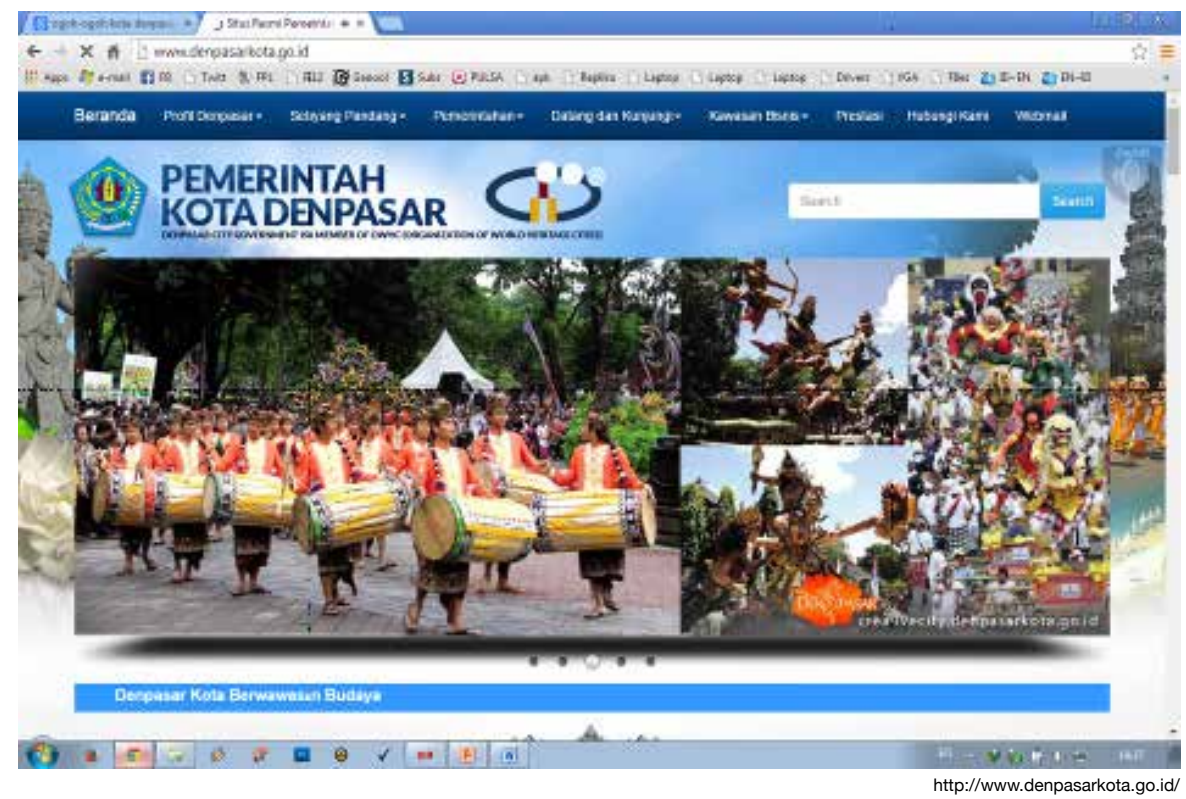

Foto 2. Salah satu bentuk sosialisasi tradisi ogoh-ogoh melalui website Kota Denpasar.

pariwisata, sosialisasi dan promosi mutlak diperlukan. Pemerintah Kota Denpasar melalui situs resmi pemerintah kota www.denpasarkota.go.id juga berupaya untuk mensosialisasikan tradisi ogoh-ogoh melalui tampilan website yang bertemakan pawai ogoh-ogoh (lihat Foto 2). Selain melalui media cetak dan internet, pihak Dinas Pariwisata Kota Denpasar juga telah memasukkan parade ogoh-ogoh dalam kalender kepariwisataan (calendar of events) Kota Denpasar secara rutin setiap tahunnya.

Hanya saja selama ini menurut pihak Dinas Pariwisata Kota Denpasar tidak menjalin kerjasama dengan pihak asosiasi pariwisata dalam melakukan promosi yang mengkhusus mengenai parade ogoh-ogoh. Promosi yang selama ini dilakukan oleh Pemerintah Kota Denpasar terkait parade ogohogoh masih kurang terutama infomasi ke pihak pelaku pariwisata khususnya travel agent, padahal parade ogoh-ogoh di Kota Denpasar memiliki daya tarik tersendiri bagi wisatawan, sehingga travel agent bekerja secara mandiri dalam mempromosikan parade ogoh-ogoh di Kota Denpasar.

\section{Kontribusi Parade Ogoh-ogoh bagi Pariwisata Budaya Kota Denpasar}

Parade ogoh-ogoh sebagai salah satu event budaya yang diselenggarakan di Kota Denpasar telah berkontribusi secara tidak langsung bagi pengembangan pariwisata budaya di Kota Denpasar. Suatu event dapat dikatakan memberikan kontribusi bagi suatu destinasi wisata secara berkelanjutan apabila (1) mampu mendatangkan pengunjung di luar musim puncak liburan (peak season) dan berkontribusi terhadap keberlanjutan 


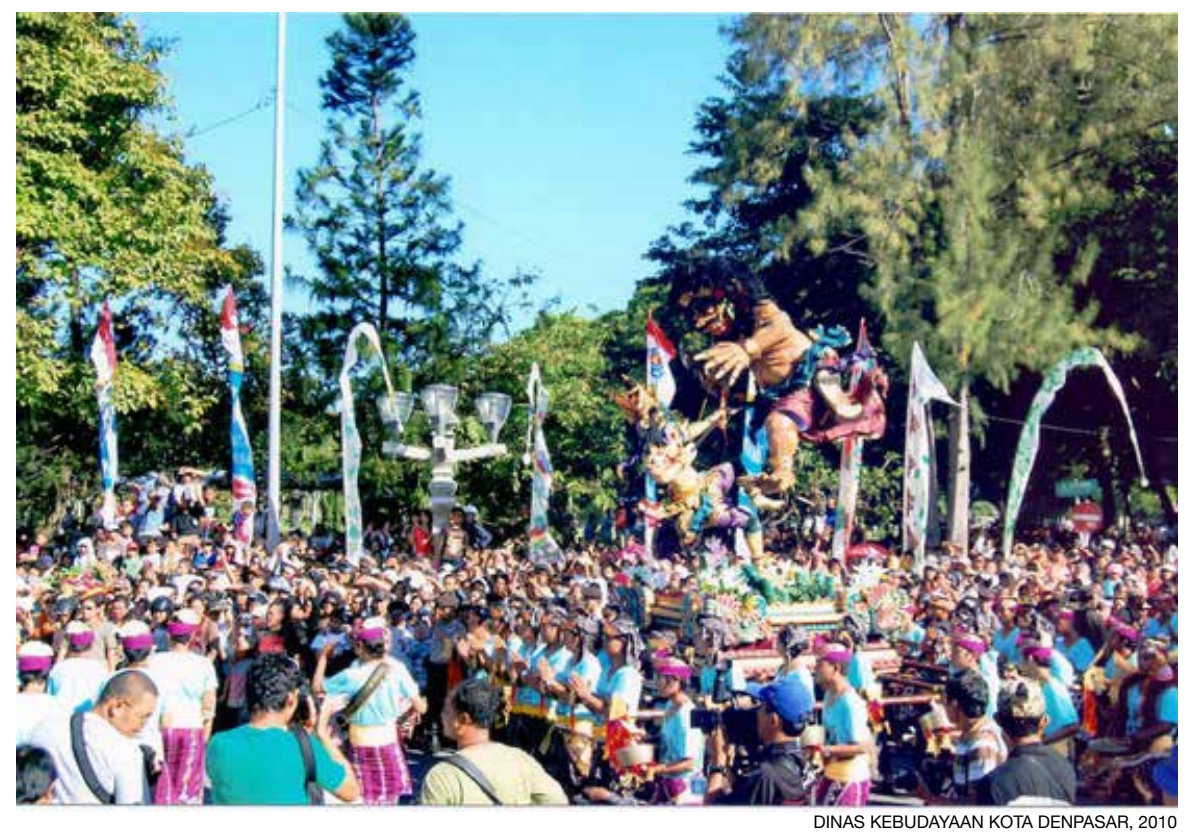

Foto 3. Antusiasme masyarakat menyaksikan parade ogoh-ogoh.

ekonomi destinasi; (2) dapat menumbuhkan kepedulian destinasi untuk meningkatkan permintaan wisatawan; serta (3) dapat menarik perhatian isu-isu sosial budaya dan kelestarian lingkungan sehingga memperkaya pengetahuan peserta event dan juga pengunjung (Mair, 2013:4).

Atraksi pawai ogoh-ogoh yang digelar setiap tahunnya sehari menjelang Hari Raya Nyepi merupakan salah satu upaya yang ditempuh Pemerintah Kota Denpasar untuk memposisikan Denpasar menjadi sebuah destinasi yang mengembangkan pariwisata berbasis budaya unggulan. Atraksi pawai ogoh-ogoh diharapkan dapat menjadi salah satu ikon budaya di Kota Denpasar sehingga dapat menarik minat wisatawan yang secara tidak langsung nantinya dapat meningkatkan jumlah kunjungan maupun jumlah wisatawan yang menginap di Kota Denpasar.

Meskipun secara statistik belum ditemukan data mengenai wisatawan yang bertujuan untuk menyaksikan event parade ogoh-ogoh yang digelar di catus pata Catur Muka Kota Denpasar setiap tahunnya, ketertarikan wisatawan mengenai parade ogoh-ogoh salah satunya dapat diketahui melalui kepuasan wisatawan terhadap event parade ogoh-ogoh. Berdasarkan hasail wawancara dengan beberapa travel agent di Kota Denpasar menunjukkan bahwa parade ogoh-ogoh di Kota Denpasar mendapat sambutan positif dari pelaku pariwisata dan wisatawan lihat Foto 3). Hanya saja sebagai atraksi wisata, parade ogoh-ogoh masih harus perlu dibenahi terutama dari segi pengaturan tempat bagi penonton, agar wisatawan dan masyarakat dapat 
dengan aman dan nyaman menikmati pertunjukan parade ogoh-ogoh.

Sebagai salah satu event budaya yang dikembangkan di Kota Denpasar, parade ogoh-ogoh telah mampu mendukung perkembangan industri kreatif dan memberikan peluang usaha bagi masyarakat maupun pengusaha lokal. Peluang usaha industri rumahan, seperti penjualan berbagai bahan yang dipergunakan dalam pembuatan ogoh-ogoh serta serta industri budaya yang kini sudah mulai membuat ogoh-ogoh untuk dijual kepada masyarakat dari ukuran kecil (ogoh-ogoh mini) yang diperuntukkan bagi anak-anak hingga ogoh-ogoh yang berukuran besar.

Meningkatnya penghasilan industri rumah tangga lainnya seperti usaha makanan maupun minuman menjelang perayaan Hari Raya Nyepi maupun pada saat pelaksanaan parade ogoh-ogoh, usaha konveksi yang menerima pesanan pembuatan pakaian seragam peserta parade. Tersedianya berbagai ragam pilihan hotel di Kota Denpasar dengan lokasi yang menyebar di seluruh wilayah Kota Denpasar dapat memudahkan wisatawan dalam menentukan pilihannya untuk menginap di Kota Denpasar sebelum, selama maupun sesudah parade ogoh-ogoh berlangsung. Mengingat parade ogoh-ogoh di Kota Denpasar diselenggarakan sehari menjelang Hari Raya Nyepi, maka keesokan harinya wisatawan akan memperoleh pengalaman menikmati suasana Nyepi di Bali.

Melalui penyelenggaraan parade ogoh-ogoh sebagai event budaya di Kota Denpasar telah berkontribusi sebagai media pendidikan untuk masyarakat maupun wisatawan. Parade ogoh-ogoh telah memberikan peluang bagi para wisatawan untuk memperkaya pengalaman budayanya mengenai tradisi ogoh-ogoh dan juga bagi masyarakat Kota Denpasar untuk terus mempertahankan dan melestarikan keberadaan tradisi ogoh-ogoh (Picard, 2006:167-170). Diwajibkannya bagi sekaa teruna peserta seleksi untuk menggunakan bahan tradisional, seperti menggunakan bambu, kayu dan bahan lainnya asalkan tidak bahan sterofoam pada penyelenggaraan parade ogoh-ogoh tahun 2015 menunjukkan adanya kepedulian mengenai dampak terhadap lingkungan akibat penggunaan sterofoam sebagai bahan pembuatan ogoh-ogoh.

Prosesi ogoh-ogoh merupakan salah satu bukti bahwa tradisi atau adat, seni dan agama Hindu di Bali saling berkaitan dan berhubungan. Hal mendasar dari tradisi adalah pengetahuan dan nilai kebudayaan yang diteruskan setiap generasi melalui proses pembelajaran baik tertulis maupun lisan Nilai-nilai budaya inilah yang diwariskan melalui proses pembelajaran sehingga tetap hidup dalam masyarakat (Kusuma, 2014:34). Pawai ogoh-ogoh menjelang Hari Raya Nyepi dapat dikatakan sebagai tradisi baru. Sebagaimana diungkapkan dalam penelitian Noszlopy (2003) disebutkan bahwa ogoh-ogoh kini telah menjadi tradisi baru yang sangat populer sebagai bagian dari ritual tahunan yang berlangsung pada malam 
sebelum Nyepi di Bali.

Dalam pembuatan ogoh-ogoh, masyarakat Hindu di Bali merujuk pada ajaran agama Hindu di Bali yang pada dasarnya adalah konsep satyam (kebenaran), siwam (kebajikan) dan sundaram (keindahan) (Pemayun, 2010:6). Hasil karya seni yang dihasilkan yang diwujudkan dalam bentuk ogoh-ogoh oleh masyarakat Hindu di Bali merupakan ungkapan rasa bakti dalam agama Hindu yang digunakan dalam rangkaian upacara Bhuta Yadnya pada saat pangerupukan. Kreativitas seni berupa ogoh-ogoh inilah yang kemudian menjadi daya tarik dalam perkembangan kepariwisataan di Bali pada umumnya dan di Denpasar pada khususnya. Seperti dapat disaksikan hampir di seluruh wilayah Bali, atraksi pawai ogoh-ogoh pada malam pangerupukan sehari menjelang Hari Raya Nyepi di Kota Denpasar tidak hanya menarik perhatian masyarakat lokal, tetapi juga wisatawan domestik maupun mancanegara.

Terkait dengan keberadaan Bali sebagai destinasi pariwisata internasional yang cukup populer, menyebabkan Kota Denpasar tidak luput dari berbagai pengaruh global, namun demikian namun demikian nuansa tradisi masih tampak mewarnai penampilan Kota Denpasar sebagai kota budaya (Mardika, dkk, 2010:25; Wirawan, dkk, 2011:130). Masyarakat Kota Denpasar masih tetap mencintai serta mempunyai kesadaran untuk memelihara dan mempertahankan tradisi yang telah diwariskan dari generasi ke generasi termasuk tradisi ogoh-ogoh.

Terdapat aktivitas budaya yang unik dan menarik dengan elemenelemen budaya yang berakar pada unsur-unsur tradisi lama pada prosesi ogoh-ogoh (Pemayun, 2010:1). Atraksi pawai ogoh-ogoh sebagai salah satu event budaya yang dikembangkan di Kota Denpasar merupakan bentuk kreativitas masyarakat Hindu di Bali, khususnya di Kota Denpasar dalam memaknai filosofis perayaan pergantian Tahun Saka. Sebagai salah satu modal budaya pembangunan di Kota Denpasar, parade ogoh-ogoh telah memenuhi aspek-aspek yang dapat dianggap menjadi ciri khusus Denpasar sebagai kota budaya di antaranya (1) parade ogoh-ogoh merupakan salah satu event budaya di Kota Denpasar, (2) tradisi ogoh-ogoh telah diwariskan dari generasi ke generasi, (3) ogoh-ogoh merupakan salah satu unsur budaya unggulan Kota Denpasar serta (4) makna filosofis ogoh-ogoh dapat diterapkan dalam kehidupan sehari-hari masyarakat Kota Denpasar.

Terpenuhinya aspek-aspek yang dapat dianggap sebagai ciri khusus Denpasar sebagai kota budaya parade ogoh-ogoh secara tidak langsung memberikan kontribusi bagi pengembangan Denpasar sebagai kota budaya. Dikategorikannya parade ogoh-ogoh sebagai hallmark event maka parade ogoh-ogoh dapat digunakan untuk mengembangkan citra positif Denpasar sebagai kota budaya. Penyelenggaraan parade ogoh-ogoh di Kota Denpasar juga sangatlah efektif. Ini dapat dibuktikan dengan ditampilkannya ogoh- 


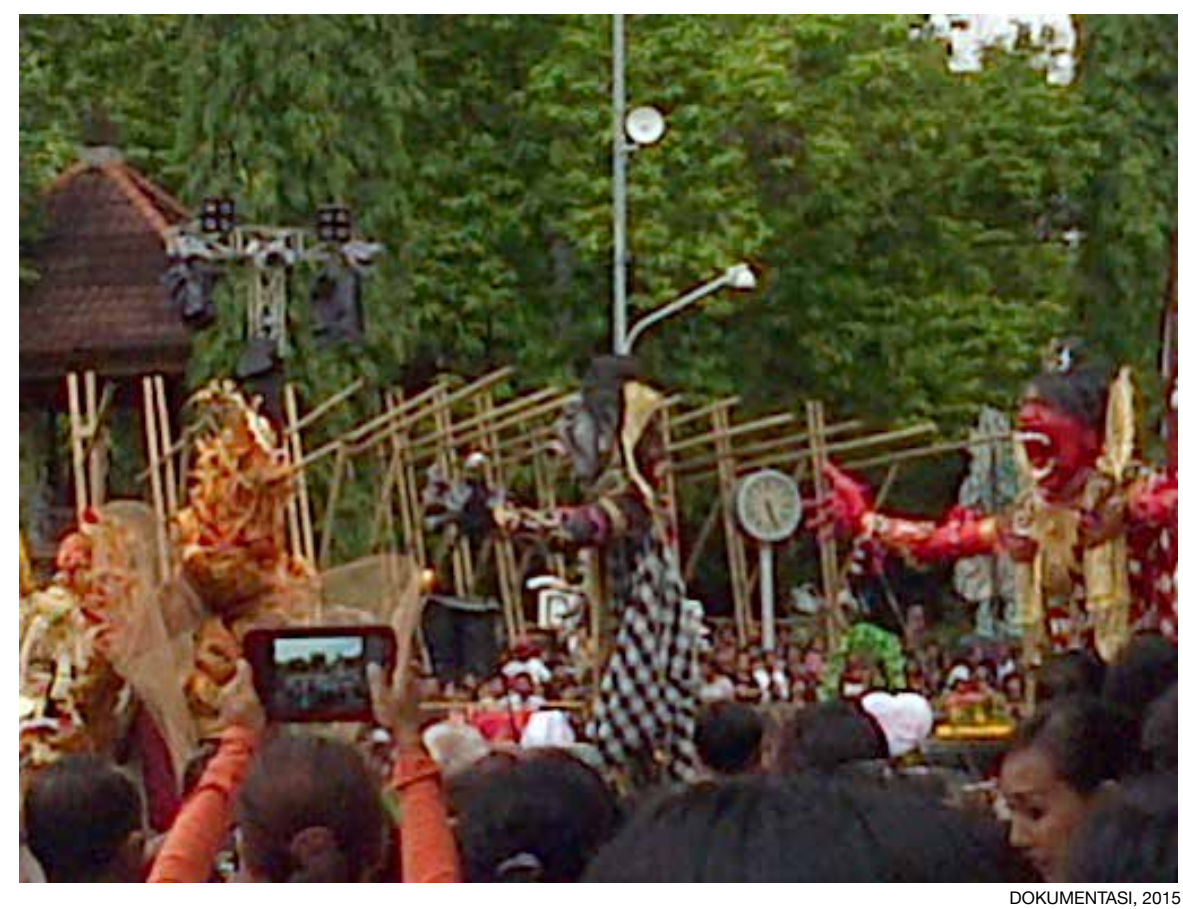

Foto 4. Penampilan ogoh-ogoh pada pawai pembukaan Denpasar Festival tahun 2014.

ogoh tidak hanya pada saat parade menjelang Hari Raya Nyepi, namun juga pada penyelenggaraan event-event budaya lainnya di Kota Denpasar, seperti pada pawai pembukaan Pesta Kesenian Bali (PKB) ke-32 tahun 2010 dan pawai pembukaan Denpasar Festival tahun 2014 (lihat Foto 4).

Melalui penyelenggaraan parade ogoh-ogoh dapat menampung kreativitas pemuda (sekaa teruna) dalam kegiatan yang bersifat positif sehingga dapat menumbuhkembangkan kreativitas seni dan budaya secara berjenjang dan berkesinambungan. Dengan diselenggarakannya parade ogoh-ogoh secara tidak langsung telah melestarikan dan mengembangkan tradisi ogoh-ogoh, sehingga sebagai salah satu unsur budaya unggulan Kota Denpasar keberadaan tradisi ogoh-ogoh masih terpelihara sampai sekarang.

Parade ogoh-ogoh dapat menjadi wahana untuk mensosialisasikan pesanpesan agama maupun kesenian yang dapat diterapkan dalam kehidupan sehari-hari masyarakat. Melalui penyelenggaraan parade ogoh-ogoh, maka nilai-nilai sastra yang dipakai sebagai acuan dalam pembuatan ogoh-ogoh secara tidak langsung dapat menambah pengetahuan tidak hanya bagi pembuat ogoh-ogoh namun juga bagi masyarakat maupun bagi wisatawan yang menikmati karya ogoh-ogoh itu sendiri. Selain pesan agama, melalui parade ogoh-ogoh juga sarat akan pesan kesenian yang disajikan melalui pertunjukan atraksi pawai ogoh-ogoh oleh sekaa teruna. Penampilan ogoh-ogoh peserta yang disertai dengan penataan gerak tari ogoh-ogoh 
yang diiringi dengan gamelan memiliki daya tarik bagi masyarakat yang menyaksikannya.

Berdasarkan hasil analisis model evaluasi CIPP dapat diketahui bahwa kegiatan parade ogoh-ogoh, khususnya parade ogoh-ogoh tahun 2014 telah menunjukkan keberhasilan dari segi konteks, masukan dan produk, hanya saja dari segi proses belum berjalan secara maksimal sehingga masih memerlukan adanya pembenahan untuk pelaksanaan parade ke depannya terutama dari segi tahapan sosialisasi dan seleksi. Dengan keberhasilan pelaksanaan parade ogoh-ogoh yang sesuai dengan tujuan pelaksanaan maka secara tidak langsung berkontribusi bagi pengembangan Denpasar sebagai kota budaya.

\section{Strategi Pelaksanaan Parade Ogoh-ogoh di Kota Denpasar}

Strategi merupakan keseluruhan gagasan yang berkaitan dengan perencanaan sampai dengan pelaksanaan gagasan tersebut. Strategi yang dimaksud adalah gagasan-gagasan yang diperuntukkan bagi pemerintah terkait pelaksanaan parade ogoh-ogoh. Parade ogoh-ogoh di Kota Denpasar memiliki potensi sebagai produk pariwisata sehingga memerlukan usahausaha intensif untuk dapat bersaing dengan atraksi wisata lainnya di daerah lainnya. Berikut diuraikan strategi peningkatan parade ogoh-ogoh sebagai event budaya untuk mendukung pengembangan pariwisata budaya di Kota Denpasar.

\subsection{Strategi Pelaksanaan Lomba}

Terdapat beberapa langkah yang perlu dilaksanakan terkait pelaksanaan parade ogoh-ogoh di Kota Denpasar, antara lain: pemberian daftar sumbersumber sastra agama yang dapat dijadikan referensi dalam memilih atau menetapkan bentuk ogoh-ogoh, pemahaman masyarakat mengenai fungsi dan makna ogoh-ogoh dapat ditingkatkan dengan memberikan pencerahan melalui media cetak maupun media eletronik. Pemerintah Kota Denpasar perlu memperketat aturan mengenai ogoh-ogoh, seperti menetapkan standarisasi mengenai bahan, bentuk dan tema ogoh-ogoh serta melarang penggunaan musik modern sebagai musik pengiring pada saat pengarakan ogoh ogoh.

Untuk meningkatkan kreativitas dan sportivitas generasi muda dalam membuat ogoh-ogoh serta mengarahkan kegiatan malam pangerupukan agar lebih tertib dan terorganisir dapat dilakukan melalui sistem lomba ogoh-ogoh dengan kriteria dengan dua kriteria lomba terdiri atas ogoh-ogoh tradisional dan ogoh-ogoh kreasi baru. Sistem pelaksanaan parade ogohogoh yang digelar dalam format lomba akan meningkatkan minat sekaa teruna untuk berpartisipasi. Agar penilaian yang diberikan lebih adil dan objektif, maka yang melakukan penilaian sebaiknya melibatkan juri yang 
diajukan oleh masing-masing peserta lomba. Berdasarkan kriteria penilaian yang telah disepakati, masing-masing juri melakukan penilaian terhadap seluruh ogoh-ogoh peserta lomba, kecuali untuk ogoh-ogoh yang berasal dari wilayah yang diwakilinya.

Agar lebih transparan serta tidak muncul keraguan maupun kecurigaan terkait dengan hasil seleksi maupun hasil lomba, ada baiknya pada saat pengumuman selain mencantumkan nilai-nilai peserta yang lolos seleksi dan pemenang lomba agar mencantumkan juga nilai dari seluruh peserta secara lebih terinci berdasarkan masing-masing kriteria penilaian. Terkait dengan nilai yang diberikan, tim juri agar memberikan penjelasan meliputi kelebihan maupun kekurangan masing-masing peserta.

\subsection{Strategi Peningkatan Promosi}

Masih minimnya promosi terkait dengan penyelenggaraan parade ogohogoh secara tidak langsung juga ikut mempengaruhi kunjungan wisatawan ke Kota Denpasar karena tidak semua wisatawan mengetahui tentang pawai ogoh-ogoh di Kota Denpasar. Kunci utama kedatangan wisatawan atau suksesnya program pariwisata sangat bergantung pada strategi promosi yang dilakukan. Strategi promosi merupakan seluruh kegiatan yang meliputi perencanaan, pelaksanaan dan pengendalian dilakukan oleh organisasi untuk bisa mencapai tujuan-tujuan yang telah ditetapkan (Tjiptono, 2002:233).

Dalam pelaksanaan promosi parade ogoh-ogoh di Kota Denpasar, selain melalui media cetak dan internet, pihak Dinas Pariwisata Kota Denpasar juga telah memasukkan parade ogoh-ogoh dalam kalender kepariwisataan (calendar of events) Kota Denpasar. Hanya saja selama ini, pihak Dinas Pariwisata Kota Denpasar tidak menjalin kerjasama dengan pihak asosiasi pariwisata dalam melakukan promosi yang mengkhusus mengenai parade ogoh-ogoh. Berkenaan dengan promosi parade ogoh-ogoh di Kota Denpasar, terdapat beberapa strategi promosi yang perlu dilaksanakan dalam rangka pengembangan parade ogoh-ogoh sebagai produk wisata budaya di Kota Denpasar, sebagai berikut.

Pertama, untuk menginformasikan berbagai pesan terkait parade ogohogoh, selain memanfaatkan media yang telah digunakan selama ini dapat dilakukan juga dengan memasang iklan di majalah-majalah beberapa hotel yang ada di Denpasar. Memasang iklan di majalah hotel bertujuan menyampaikan pesan kepada wisatawan yang menginap di Denpasar tentang keberadaan event parade ogoh-ogoh di Kota Denpasar.

Kedua, agar pelaksanaan parade ogoh-ogoh sebagai event wisata budaya di Kota Denpasar dapat berkerlanjutan, sangatlah penting untuk melibatkan industri parwisata dan pengusaha lokal dalam persiapan pelaksanaan parade. Pemerintah Kota Denpasar perlu menjalin kerja sama dengan biro perjalanan wisata dan organisasi pariwisata seperti: ASITA, PHRI dan HPI 
dalam menetapkan kalender kepariwisataan (calendar of events) Kota Denpasar dan juga mempromosikan parade ogoh-ogoh di Kota Denpasar sehingga terbentuk suatu sinergi kemitraan yang saling mengisi.

Ketiga, menyediakan souvenir yang berkaitan dengan ogoh-ogoh seperti miniatur ogoh-ogoh, gantungan kunci, postcard maupun baju dengan desain ogoh-ogoh sebagai salah satu souvenir khas dari Kota Denpasar. Dengan adanya souvenir ini diharapkan dapat menarik minat wisatawan untuk menyaksikan parade ogoh-ogoh di Kota Denpasar. Selain sebagai upaya memperkuat citra Kota Denpasar sebagai kota budaya, melalui penyediaan souvenir ini diharapkan akan dapat menciptakan lapangan usaha baru bagi masyarakat.

Keempat, untuk lebih memperluas informasi mengenai parade ogohogoh di Kota Denpasar dapat dilakukan dengan memanfaatkan teknologi informasi berbasis web sebagai sarana promosi. Sarana promosi ini dapat tersedia dalam bentuk website dan media online lainnya, seperti facebook dan twitter yang khusus memberikan layanan informasi mengenai ogohogoh yang dikemas secara menarik dan atraktif serta dikelola secara profesional.

\section{Simpulan dan Saran}

Sebagai salah satu event budaya yang dikembangkan di Kota Denpasar, parade ogoh-ogoh telah memenuhi kriteria/unsur-unsur agar suatu event dapat berlangsung yang meliputi tujuan, tema, produk, lokasi, peserta serta adanya pihak penyelenggara. Untuk menjaga kualitas dan entitas penyelenggaraan parade ogoh-ogoh sebagai salah satu event di Kota Denpasar, tentunya perlu dilakukan evaluasi. Selama ini belum ada indikator yang dapat dijadikan sebagai dasar dalam melakukan evaluasi, sehingga evaluasi yang dilakukan belum secara menyeluruh. Evaluasi yang telah dilakukan seperti mengenai waktu sosialiasi, keterlibatan tim panitia dan mengenai protes dari peserta seleksi.

Evaluasi parade ogoh-ogoh dalam artikel ini merujuk pada model evaluasi CIPP yang berfokus pada empat aspek yaitu context (konteks), input (masukan), process (proses) dan product (produk) dengan masing-masing indikator yang meliputi indikator perencanaan, indikator sumber daya, indikator pelaksanaan dan indikator keluaran. Berdasarkan hasil analisis model evaluasi CIPP dapat diketahui bahwa kegiatan parade ogoh-ogoh, khususnya parade ogoh-ogoh tahun 2014 telah menunjukkan keberhasilan dari segi konteks, masukan dan produk, hanya saja dari segi proses belum berjalan secara maksimal dan masih memerlukan adanya pembenahan terutama dari segi tahapan sosialisasi dan seleksi dalam pelaksanaan parade ogoh-ogoh ke depannya.

Parade ogoh-ogoh yang diselenggarakan sehari menjelang Hari Raya 
Nyepi di Kota Denpasar memberikan kontribusi bagi pengembangan Denpasar sebagai kota budaya. Parade ogoh-ogoh juga berkontribusi sebagai pendukung Denpasar dalam mengembangkan pariwisata budaya. Strategi yang efektif untuk dapat bersaing dengan atraksi wisata lainnya di daerah lainnya terkait pelaksanaan parade ogoh-ogoh sebagai event budaya adalah dengan strategi intensif yang terdiri atas strategi pelaksanaan lomba dan strategi peningkatan promosi.

Untuk lebih mengoptimalkan parade ogoh-ogoh sebagai event budaya di Kota Denpasar, maka dapat dikemukakan saran antara lain: untuk mengarahkan kegiatan malam pangerupukan agar lebih tertib dan terorganisir dapat dilakukan melalui sistem lomba ogoh-ogoh dengan dua kriteria lomba terdiri atas ogoh-ogoh tradisional dan ogoh-ogoh kreasi baru; agar penilaian yang diberikan lebih adil dan objektif, maka yang melakukan penilaian sebaiknya melibatkan juri yang diajukan oleh masing-masing peserta lomba; untuk meminimalisir kecurigaan terkait hasil nilai lomba, tim juri sebaiknya memberikan penjelasan terkait dengan nilai yang diberikan dan dirinci untuk masing-masing peserta.

Memberikan pencerahan tentang fungsi dan makna ogoh-ogoh melalui media cetak maupun media eletronik; Pemerintah Kota Denpasar perlu memperketat aturan mengenai ogoh-ogoh, seperti menetapkan standarisasi mengenai bahan, bentuk dan tema ogoh-ogoh serta melarang penggunaan musik modern sebagai musik pengiring pada saat pengarakan ogoh ogoh; lebih diintensifkan lagi kerjasama yang telah terjalin selama ini antara Pemerintah Kota Denpasar dengan organisasi pariwisata dan biro perjalanan wisata dalam menetapkan kalender kepariwisataan (calendar of events) Kota Denpasar dan juga mempromosikan parade ogoh-ogoh di Kota Denpasar; menyediakan sarana promosi dalam bentuk website dan media online lainnya yang khusus memberikan layanan informasi mengenai ogohogoh; menyediakan tempat yang khusus bagi wisatawan untuk menonton parade ogoh-ogoh; menyediakan souvenir yang bertema ogoh-ogoh, seperti miniatur ogoh-ogoh, gantungan kunci, postcard maupun baju dengan desain ogoh-ogoh.

\section{Ucapan Terima Kasih}

Penulis mengucapkan terima kasih yang sebesar-besarnya kepada Prof. Dr. I Nyoman Darma Putra, M.Litt., selaku Ketua Program Studi Magister Kajian Pariwisata sekaligus Pembimbing I yang dengan penuh perhatian telah memberikan dorongan, arahan, bimbingan dan saran kepada penulis dalam penyelesaian penelitian ini. Terima kasih yang sebesar-besarnya pula penulis sampaikan kepada Dr. Drs. Ida Bagus Gde Pujaastawa, M.A., selaku Pembimbing II yang dengan penuh perhatian dan kesabaran telah memberikan bimbingan dan saran kepada penulis. Pada kesempatan ini, 
penulis juga menyampaikan rasa terima kasih kepada para dosen penguji, Prof. Dr. I Wayan Ardika, M.A., Prof. Dr. I Nyoman Kutha Ratna, SU dan Dr. I Gede Mudana, M.Si, yang telah memberikan masukan, saran dan koreksi untuk menyempurnakan tulisan ini. Terlaksananya penelitian ini tidak lepas dari bantuan berbagai pihak khususnya dari para informan yang telah bersedia meluangkan waktunya serta berbagai pihak yang tidak mungkin disebutkan satu persatu di sini. Oleh karena itu, pada kesempatan ini penulis mengucapkan terima kasih kepada semua pihak yang telah membantu dalam proses penelitian hingga terwujudnya artikel ini.

\section{Daftar Pustaka}

Bappeda Kota Denpasar. 2011. Event Management Kota Denpasar. Denpasar: Bappeda Kota Denpasar.

Dinas Kebudayaan Kota Denpasar. 2011. Buku Panduan Ogoh-ogoh Pengerupukan. Denpasar: Dinas Kebudayaan Kota Denpasar.

Geriya, I W., Murjanayasa, I GW., Suputra, P.M., Sukardja, P., Sutriawan, K.M., Mardika, I N., \& Astrawan, I M. 2010. Kebudayaan Unggul Inventori Unsur Unggulan sebagai Basis Kota Denpasar Kreatif. Denpasar: Bappeda Kota Denpasar.

Indrayana, K.A. 2006. "Ogoh-ogoh dalam Ritual Nyepi di Bali: Sebuah Kajian Budaya" (tesis). Denpasar: Universitas Udayana.

Keputusan Presiden Nomor 3 Tahun 1983 tentang Perubahan Atas Keputusan Presiden Nomor 251 Tahun 1967 tentang Hari-Hari Libur Sebagaimana Telah Beberapa Kali Diubah Terakhir dengan Keputusan Presiden Nomor 10 Tahun 1971.

Kusuma, N.W., Jelantik, I.B., Sukayasa, I W., Putra, I.B.R., Argawa, I N., Sukarma, I W., \& Pratama, P.A.S. I Wayan Sukarma (Editor). 2014. Ide-ide Prof. Dr. Ida Bagus Mantra tentang Tradisi Bali. Denpasar: Dinas Kebudayaan Kota Denpasar.

Krosbacher, M.C. 2010. "Authenticity and the Use of Multimedia at Cultural Tourist Attractions" (thesis). Irlandia: Dublin Institute of Technology.

Mahadewi, N.M.E. 2012. Atraksi, Produk Wisata dan Event Wisata dari Teori ke Praktik dalam Jurnal Perhotelan dan Pariwisata, Agustus 2012, Volume 2, Nomor 1, Hal.1-10 (serial online). [www.triatmajaya.triatma-mapindo.ac.id diakses pada tanggal 18 Januari 2014].

Mair, J. 2013. The Role of Events in Creating Sustainable Tourism Destinations. (Presentation Paper). Australia: Monash University. (serial online), [cited 2015 April 23rd]. Available from:URL: business.curtin.edu.au/.../mair_curtin_ presentation.pdf

Mardika, I N., Mardika, I M., \& Laksmi, A.A.R.S. I Wayan Geriya (Editor). 2010. Pusaka Budaya Representasi Ragam Pusaka dan Tantangan Konservasi di Kota Denpasar, Bali. Denpasar: Bappeda Kota Denpasar. 
Moleong, L.J. 2014. Metodologi Penelitian Kualitatif. (Edisi Revisi). Bandung: Remaja Rosdakarya.

Noszlopy, L. 2003. Tracking 'New Traditions' in a (Post) Modern Balinese-Indonesian Context on Research Issue In Art Design and Media. ISSN 1474-2365 (serial online), [cited 2014 January 18th]. Available from:URL: www.biad.bcu.ac.uk/ research/.../riadm_issue4.pdf.

Pemayun, T.U.N. 2010. Tinjauan Seni Rupa Patung Ogoh-ogoh Jilid I. Denpasar: Sari Kahyangan Indonesia.

Picard, M. 2006. Bali: Pariwisata Budaya dan Budaya Pariwisata. Jakarta: KPG (Kepustakaan Populer Gramedia).

Sugiyono. 2009. Metode Penelitian Bisnis (Pendekatan Kuantitatif, Kualitatif dan $R \& D$. (Cetakan Keempat Belas). Bandung: Alfabeta.

Tjiptono, F. 2002. Strategi Pemasaran. (Edisi II Cetakan Keenam). Yogyakarta: ANDI.

Wirawan. 2012. Evaluasi Teori, Model, Standar, Aplikasi dan Profesi. Jakarta: Rajawali Pers PT Raja Grafindo Persada.

\section{Profil Penulis}

Ni Luh Putu Aristrawati adalah alumni Program Studi Magister Kajian Pariwisata Universitas Udayana. Menyelesaikan program Diploma IV di Fakultas Pariwisata, Universitas Udayana tahun 2007. Pengalaman yang dimiliki di bidang pariwisata adalah pernah bekerja pada hotel di Nusa Dua, Kecamatan Kuta Selatan-Kabupaten Badung. 